\title{
COMMUNICATIVE COMPETENCE IN ENGLISH AND ITS DEVELOPMENT AT THE PRIMARY LEVEL OF EDUCATION
}

\section{[KOMUNIKACNA KOMPETENCIA V ANGLICKOM JAZYKU A JEJ ROZVOJ NA PRIMARNOM STUPNI VZDELAVANIA]}

\author{
Klaudia Paulikova
}

doi: 10.18355/PG.2021.10.1.3

\begin{abstract}
Development of communicative competence has become one of the most important aspects of foreign language education in the modern days. The study portrays the development of communicative competence at the primary level of education in Slovakia. The main aim of the inquiry is to identify and examine the process of developing communicative competence at the given level of proficiency by a qualitative enquiry with the use of content analysis, observation, and interview. The results and findings depict how the components of communicative competence are referred to in real teaching environment. The findings reveal that several linguistic components of communicative competence prevail in the teaching process, whereas sociolinguistic and pragmatic language use is rather neglected.
\end{abstract}

\section{Key words}

communicative competence, linguistic competence, sociolinguistic competence, pragmatic competence, primary education, foreign language education

\section{Anotácia}

Rozvoj komunikačných kompetencií sa $\mathrm{v}$ modernej dobe stal jedným $\mathrm{z}$ najdôležitejších aspektov výučby cudzích jazykov. Štúdia zobrazuje vývoj komunikačných kompetencií na primárnom vzdelávaní na Slovensku. Hlavným ciel'om výskumu je identifikovat' a preskúmat' proces rozvoja komunikačných kompetencií na danej úrovni pomocou kvalitatívneho výskumu použitím troch výskumných metód - obsahovej analýzy, pozorovania a rozhovoru. Výsledky poukazujú na to, ako sú jednotlivé zložky komunikačnej kompetencie chápané a zahŕňané vo vyučovacom procese. Bolo zistené, že určité lingvistické zložky komunikačných kompetencií prevládajú, zatial' čo sociolingvistické a pragmatické používanie jazyka je skôr zanedbávané.

\section{Kl’účové slová}

komunikačná kompetencia, lingvistická kompetencia, sociolingvistická kompetencia, pragmatická kompetencia, primárny stupeň vzdelávania, vyučovanie cudzích jazykov 


\section{Úvod}

Rozvoj komunikačnej kompetencie je jedným z najvýznamnejších aspektov cudzojazyčného vzdelávania. Poukazuje na schopnost' používat' jazyk v akejkol'vek situácii a za akýchkol'vek okolností. Pokial' ide o cudzojazyčné vyučovanie, je pochopitel'né, že ciel'om vyučovacieho procesu je poskytnút' študentom komplexný základ na dosiahnutie čo najvyšších poznatkov použivania jazyka na rovine teoretickej aj pragmatickej. Vzhladom na skutočnost', že moderný globálny svet vyžaduje rôznorodé kompetencie a zručnosti, ako aj schopnosti efektívne používat jazyk v rôznych oblastiach, osvojenie si komunikačnej kompetencie ako takej sa stáva jedným z hlavných ciel’ov výučby cudzích jazykov. Táto požiadavka sa odráža aj v referenčných dokumentoch pre výučbu cudzích jazykov, ktoré na národnej aj medzinárodnej úrovni označujú rozvoj komunikačnej kompetencie za kl'úč ku komplexnému osvojeniu si cudzích jazykov.

\section{Teoretické východiská}

Komunikácia a jazyk sú úzko späté. Valentzas a Broni (2014) odvodzujú slovo komunikácia $\mathrm{z}$ latinského communis, čo znamená niečo spoločné. $\mathrm{Z}$ toho vyplýva, že komunikácia ako taká poukazuje na zdiel'anie spoločného. Jazyk je jedným zo základných prostriedkov ludskej komunikácie. Vo svete rastúcej globalizácie je takmer nutnostou porozumiet' a používat' viacero jazykov počas svojho života. Používanie jednotného globálneho jazyka je vel'kou výhodou pre obchod, vedu, medzinárodné záležitosti, ale aj všeobecnú komunikáciu medzi jednotlivcami a skupinami jednotlivcov. Osvojenie si globálneho jazyka sa preto stáva jedným z hlavných ciel’ov vzdelávacích politík viacerých krajín po celom svete.

Anglický jazyk, ako jeden z globálnych jazykov, sa vyučuje už od 17. storočia. Za tento čas jeho vyučovanie prešlo mnohými zmenami. Lingvisti a učitelia pod vplyvom rôznych teoretických prístupov vyvinuli rozmanité metódy výučby jazykov, až kým sa dopracovali $\mathrm{k}$ dnešnému modernému ponímaniu. Prvým dôležitým obdobím boli roky medzi 1750 a 1880 . V tomto období vznikla gramaticko-prekladová metóda, ktorá bola zameraná na rozvoj čítania a písania $\mathrm{z}$ hl'adiska mechanického prekladu z jedného jazyka do druhého (Larsen-Freeman a Anderson, 2013). V rokoch medzi 1880 a 1920 sa začalo reformovat' cudzojazyčné vzdelávanie a vznikol nový prístup vo vyučovaní - tzv. direct method, ktorý bol zameraný na hovorenú komunikáciu (Richards a Rodgers, 2014). Vo vojnovom, medzivojnovom a povojnom období sa požiadavky na cudzie jazyky zmenili. Vzniklo niekol'ko smerov, z ktorých najdôležitejšími boli situačné vyučovanie a audiolingválny pristup. Pri situačnom vyučovaní sa schopnost' komunikácie stala dominantou, avšak vysoký dôraz sa kládol aj na štruktúru. Prvýkrát boli zavedené systematické princípy výberu, gradácie a prezentácie vyučovaného materiálu v teórii aj v praxi (Richards and Rodgers, 2014). V 40.tych rokoch minulého storočia sa preferencie zmenili kvôli svetovej vojne. Audiolingválna metóda zdôrazňovala rozvoj počúvania a hovorenia namiesto čítania a písania, ktorých rozvoj sa stal zanedbávaným (Celce-Murcia, 1991). V 70.tych rokoch potom prišiel obrovský zvrat, ktorý odštartoval celé množstvo zmien v cudzojazyčnom vzdelávaní. V komunikačnom vyučovaní 
proces výučby začal zdôrazňovat' význam a použitie jazyka namiesto pochopenia štruktúry a formy. Učitelia používali rôzne druhy aktivít a zoskupení študentov, aby iniciovali úspešné osvojovanie jazyka. Študent sa stal stredobodom vyučovacieho procesu. Prístup bol zameraný na rozvoj všetkých štyroch komunikačných zručností súčasne a v rovnakom rozsahu (Celce-Murcia, 1991).

\section{Komunikačná kompetencia}

V 70.tych rokoch sa zrodil aj pojem komunikačná kompetencia (Hymes, 1972). Vzniklo niekol'ko teoretických chápaní komunikačnej kompetencie a s nimi spolu sa zrodilo aj mnoho modelov. Už vyššie spomínaný Hymes (1972) vo svojej štúdii podotkol, že je nepostačujúce ponímat' vedomost' jazyka iba z lingvistického hl'adiska, ako Chomsky (1965) vo svojej práci referoval. Pod'la Hymesa je rovnako dôležité vediet' jazyk používat' aj na rovine konkrétnych situácií, t.j. vediet' kedy a ako správne reagovat'. Preto nazval tento fenomén komunikačná kompetencia, ktorá podl'a neho pozostávala z lingvistickej zložky a sociolingvistivkej zložky. V praktickom vyučovacom prostredí Savignon (1972) chápala komunikačnú kompetenciu ako základnú schopnost' fungovat' v komunikačnom prostredí. Roky výučby cudzích jazykov ukázali, že žiaci neboli schopní používat' predtým prijaté jazykové štruktúry, preto bolo potrebné zmenit' metódy používané pri výučbe. Študenti trénovali jazyk spontánnou interakciou a výsledky ukázali, že jazyk si osvojili ovel'a rýchlejšie ako tí, ktorým táto možnost' nebola ponúknutá. Savignon definovala komunikačnú kompetenciu ako dianie v dynamickom prostredí, kde sa všetky jej komponenty musia prispôsobit' ostatným. Popísala jav ako dynamický, medzil'udský a relatívny, ktorý je definovatel'ný iba konkrétnym kontextom (ibid.). Widdowson (1978), podobne ako Hymes a Savignon, považoval úspešné osvojenie jazyka za ovel'a viac, ako len za zvládnutie jazykových znalostí. Podl'a neho existuje silná potreba rozvíjat' komunikačné schopnosti spolu s jazykovou spôsobilost'ou, pretože ani dlhé roky štúdia cudzích jazykov nemôžu zaručit', že študenti budú schopní dobre fungovat' $\mathrm{v}$ rôznych komunikačných situáciách. Navrhol, aby sa výučba cudzích jazykov v triede rozdelila medzi jazykový kontext a komunikačný kontext, v ktorom by si študenti osvojili gramatické prostriedky jazyka a zároveň rozpoznali komunikačnú funkciu, ktorú ich výroky plnia (ibid.). Canale a Swain (1980) potom označili komunikačnú kompetenciu za kombináciu základných vedomostí a zručností používat' jazyk na komunikáciu. Ich koncepcia tohto fenoménu mala pedagogický (metodologický) charakter a pozostávala z troch základných kategórií vedomostí:

- znalost’ základných gramatických pravidiel

-znalost' používania jazyka v sociálnom kontexte $\mathrm{s}$ ciel'om plnenia komunikačných funkcií

- znalost' kombinovania rôznych typov vyjadrení s ciel'om splnit' požiadavky diškurzu

Bachman (1990) definoval tento fenomén na základe Hymesových a Widdowsonových teórií. Komunikačnú kompetenciu označil za súčast' jazykových schopností. Jeho chápanie jazykových schopností zahŕňalo nielen 
znalost' jazyka (alebo kompetencie), ale aj schopnost' ho primerane používat' v kontexte. Komunikačná, alebo jazyková kompetencia, znamenala znalost' jazyka vo všetkých možných oblastiach. Bachman zdôraznil význam používania jazyka, t.j. ako sa jazyk používa na splnenie ciel’ov v konkrétnych komunikačných situáciách.

Na základe týchto teórií vzniklo mnoho modelov komunikačnej kompetencie. Od prvotného modelu pozostávajúceho z lingvistickej a sociolingvistickej zložky sa autori postupne dopracovali $\mathrm{k}$ modernému ponímaniu, ktoré charakterizuje fenomén dnes. Popri teoretických rovinách sa pri formulácii modelov podiel'ali aj samotný Canale (1983), Bachman a Palmer (1996), Celce-Murcia et.al (1995), Celce-Murcia (2008), alebo Littlewood (2011). Všetky chápania konkrétnych komponentov komunikačnej kompetencie boli rovnako dôležité a rovnakým pomerom sa podiel'ali na vytvorení dnešného modelu, ktorý charakterizuje cudzojazyčné vzdelávanie na medzinárodnej úrovni. Nasledovný obrázok sumarizuje modely komunikačnej kompetencie vyššie uvedených autorov.

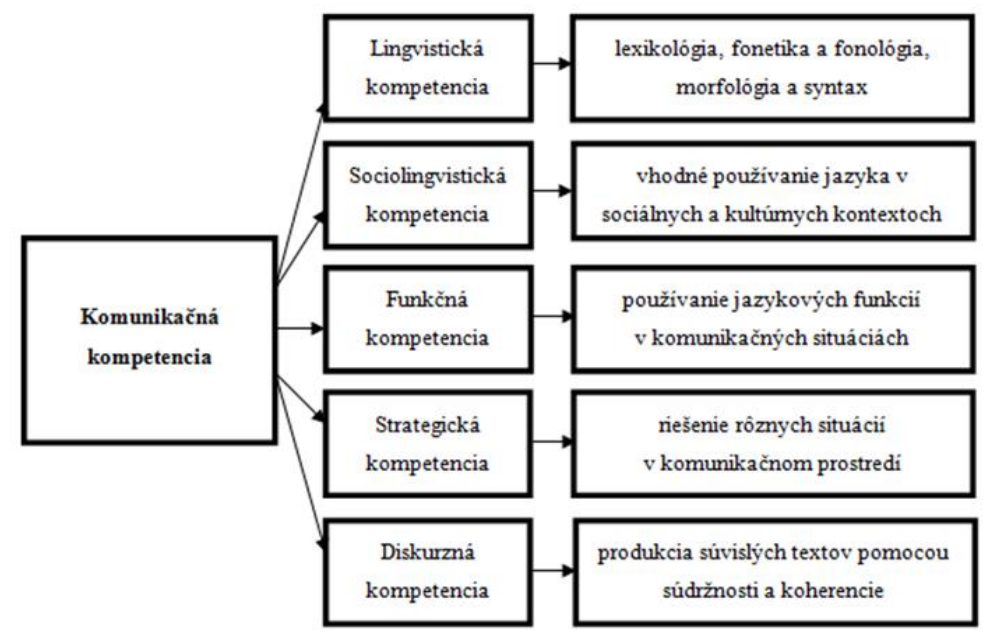

Obrázok 1. Prehl’ad komponentov komunikačnej kompetencie

\section{Komunikačná kompetencia na primárnom stupni}

Vzhl'adom na skutočnost', že konkrétne komponenty komunikačnej kompetencie sa môžu na rôznych jazykových úrovniach líšit, podrobný prehl'ad jednotlivých referenčných rámcových dokumentov poskytol dostatočné informácie ohl’adom nami zvolenej tematiky. Pri skúmaní výučby angličtiny na základných školách $\mathrm{z}$ hladiska rozvoja komunikačných kompetencií je potrebné zohl'adnit' tri hlavné referenčné dokumenty. Jedným $\mathrm{z}$ nich je, prirodzene, štátny vzdelávací program, ktorý riadi vzdelávanie na slovenských školách. Druhým dokumentom je Spoločný európsky referenčný rámec pre jazyky (CEFR), ktorý slúži ako základné usmernenie pre výučbu a štúdium jazykov $\mathrm{v}$ krajinách Európskej únie. Posledným $\mathrm{z}$ nich je Breakthrough Manuscript, rozširujúci dokument CEFR, ktorý bol vytvorený 
na účely obohatenia predchádzajúceho dokumentu pre základnú úroveň vzdelania (A1) (Pauliková, 2019).

$\mathrm{Aj}$ napriek tomu, že dokumenty popisujú jednotlivé kompetencie a ich špecifikácie mierne odlišne, celkové porovnanie dokumentov ukazuje, že spôsob chápania komunikačnej kompetencie je pre všetky tri vel'mi podobný. Celkovo tak na základnom stupni vzdelávania hovoríme o 7 skupinách kompetencií, ktoré majú dohromady 16 jednotlivých komponentov. Tieto sa rovnajú zložkám jazykovej kompetencie, sociolingvistickej kompetencie a pragmatickej kompetencie. Jazyková (alebo lingvistická) zložka pozostáva z lexikálnej kompetencie, gramatickej kompetencie, fonologickej, ortoepickej a ortografickej kompetencie. Pragmatická kompetencia pozostáva z funkčnej a diskurznej kompetencie (ibid.).

V rámci lingvistickej kompetencie by žiaci mali ovládat' určitý rozsah jednoduchých slov a slovných spojení. Mali by byt' schopní tvorit' jednoduché a zložené vety, ktoré spájajú spojky a, a ale. Mali by poznat' podstatné frázy, slovesné frázy, prídavné frázy a príslovkové frázy, ktoré sú v súlade $\mathrm{s}$ ich úrovňou znalostí. Mali by byt' schopní klást' a zodpovedat' otázky, porozumiet' a používat' niekol'ko slovných druhov (prídavné mená, zámená, podstatné mená, slovesá) a takisto aj slovotvorbu. Mali by vediet', ako rozlišovat' pohlavia (pri použití zámen), používat' jednotné a množné číslo, alebo správne používat' privlastňovanie. Mali by vediet' identifikovat' a opakovat' slová a vety, ktoré počujú, za predpokladu, že sú produkované jasne, hlasne, a so známym prízvukom. Mali by byt' schopní vytvárat' zrozumitel'né slová a vety a správne používat' slovný a vetný prízvuk, a stúpajúcu a klesajúcu intonáciu. Takisto by mali vediet' správne hláskovat' slová v rámci svojej slovnej zásoby, používat' správnu interpunkciu a správne používat' vel'ké písmená (Council of Europe, 2001; ŠPU, 2011, Trim, 2001).

$\mathrm{V}$ rámci sociolingvistickej kompetencie by mali žiaci vediet' používat' ciel'ový jazyk jednoducho $\mathrm{v}$ dobre predvídatel'nej situácii. Mali by ovládat' jednoduché pozdravy, predstavit' sa, oslovovat' l'udí a porozumiet' niektorým formám zvolaní. Študenti by navyše mali vediet', ako správne používat', prosím, ospravedlňujem sa a d'akujem v kontexte. Mali by vediet', kam vo vete umiestnit' tieto výrazy, ako ich správne použit', ked' sa pýtajú, ako pod'akovat' a vyjadrit' l'útost' (ibid.).

V rámci pragmatickej kompetencie by žiaci mali vediet' súhlasit', nesúhlasit', pýtat' si súhlas, alebo odmietnut'. Mali by byt' schopní uviest', či niečo vedia alebo nevedia, a takisto klást' $v$ tomto smere otázky. Mali by byt' tiež schopní vyjadrit' schopnost' a neschopnost' niečo urobit', a takisto klást' v tomto smere otázky. Mali by byt' schopní vyjadrit' istotu a povinnost' (ako aj zistit' ich), dat', prosit' si a odmietnut' povolenie. Mali by byt' schopní vyjadrit' želania a túžby, vyjadrit' úmysel a preferencie. Mali by byt' schopní vyjadrit' emocionálne stavy a vyjadrit’ či sa im niečo páči, alebo nie, popísat' nádeje, spokojnost', sklamanie a vd'ačnost' (a informovat' sa o nich). Nakoniec by sa mali vediet' ospravedlnit', odpustit', vyjadrit' l'ahostajnost' a l'útost'. Rovnako by mali byt' schopní použivat' jednoduchý jazyk na navrhovanie niečoho, súhlasit' s návrhom, požiadat' o niečo, vyzvat' ostatných, aby niečo urobili, prijat' alebo odmietnut' pozvanie, varovat' niekoho, niekoho radit', aby niečo urobil a ponúknut' a požiadat' o pomoc. Žiaci by mali byt' schopní prit'ahovat' 
pozornost', pozdravit' l'udí, reagovat' na pozdravy (ako v sociolingvistickej kompetencii), ako aj reagovat' na zoznamovanie sa. Mali by byt' schopní zablahoželat', navrhnút' prípitok a začat' a ukončit' rozhovor v rámci svojich lexikálnych a gramatických znalostí. Študenti by sa mali naučit' vymenovávat', váhat', opravovat' sa, zhrňovat', používat' telefón a začínat' a končit' listy alebo e-maily. Mali by vediet' použivat' také stratégie, ktoré im pomôžu pri riešení rôznych problémov (spojených s čítaním, hovorením, počúvaním a písaním). Mali by vediet', ako signalizovat' nerozumenie, požiadat' o opakovanie, objasnenie, potvrdenie porozumenia, pravopis, zapísanie vecí, vyjadrenie nevedomosti, žiadost' o pomoc alebo spomalenie. Mali by vediet' vytvárat' dlhší rozsah viet $\mathrm{v}$ reči a písaní, ktoré sú v súlade $\mathrm{s}$ rozsahom ich lexikálnych a gramatických znalostí. V neposlednom rade, mali by vediet' striedat' sa v rozhovore za predpokladu, že je predvídatel'ný alebo vedený (Council of Europe, 2001; ŠPU, 2011, Trim, 2001). Nasledujúci obrázok približuje komunikačnú kompetenciu na danej úrovni vzdelávania.

\begin{tabular}{|c|l|}
\hline Kompetencia & \multicolumn{1}{|c|}{ Zložka } \\
\hline Lexikálna & Slová a slovné spojenia \\
\hline Gramatická & Tvorba viet, frázy, slovné druhy \\
\hline Fonologická a ortoepická & Výslovnost' (zvuky, prizvuk, intonácia, atdo.) \\
\hline Ortografická & Hláskovanie a interpunkcia \\
\hline Sociolingvistická & $\begin{array}{l}\text { Pozdravy, predstavovarie sa, oslovovanie, zvolania } \\
\text { Použivanie slov prosim, đ’akujem, ospravedlnujem }\end{array}$ \\
\hline Funkčná & $\begin{array}{l}\text { Oznamovarie a pýtanie sa } \\
\text { Vyjadrovanie postojov } \\
\text { Dohovor } \\
\text { Socializovanie sa } \\
\text { Štruktúra diskurzu } \\
\text { Oprava komunikácie }\end{array}$ \\
\hline & $\begin{array}{l}\text { Tvorba dlhšieho rozsahu viet v pisomnej a hovorenej podobe } \\
\text { Striedanie sa v rozhovore }\end{array}$ \\
\hline
\end{tabular}

\section{Obrázok 2. Komponenty komunikačnej kompetencie na primárnom stupni}

Na osvojenie si týchto kompetencií existuje obrovské množstvo techník a aktivít. Ked’že neexistuje prísne stanovená metodika výučby, učitel’om sa poskytuje vel'ké množstvo zdrojov, z ktorých môžu čerpat' (Harmer, 2012). Čo sa lexikálnej kompetencie týka, Harmer (2012) navrhuje spojit' slová a frázy so zvukmi, obrázkami alebo oboma. Scrivener (2011) dodáva ako vynikajúcu techniku prezentácie nových lexikálnych textov použitie mimiky, gest, kresieb, popisov, dramatizácií, príbehov alebo slovníkovej práce. Existuje tiež niekol'ko spôsobov, ako si precvičit' slovnú zásobu, a to bud' individuálne, vo dvojiciach, $\mathrm{v}$ skupinách alebo $\mathrm{v}$ rámci celej triedy. Vypíňanie medzier, drilovanie, porovnávanie, krížovky, vyhl’adávanie slov, hry, piesne, umiestňovanie slov do správnych stípcov, dokonca aj práca so 
slovníkmi sú skvelými zdrojmi, ktoré poskytujú študentom nekonečné možnosti precvičovania jazyka (ibid.).

Pri gramatickej kompetencii autori odporúčajú aktivity ako napríklad drilovanie, písomné cvičenia, a dialógy (Scrivener, 2011). Rinvolucri and Davis (1995) navrhujú rôzne sút'aživé, kolaboratívne a drámové hry, ako aj aktivity zamerané na zvyšovanie povedomia ako vynikajúce zdroje pre gramatickú prax. Netto-Shek (2009) tieto aktivity rozdeluje na slovné a vetné. Cuncil of Europe (2001) navrhuje vyplńnanie medzier, vetné konštrukcie, cvičenia s možnost'ou výberu, substitučné cvičenia, alebo preklady.

Na rozvoj fonologickej kompetencie je najdôležitejšie poskytnút' žiakom príležitost' správne počut' jazyk (Homolová, 2016). Gower (1995) vysvetl'uje, že je nevyhnutné zaoberat' sa zvukmi, ktoré materinský jazyk študentov neobsahuje. To sa dá dosiahnut použitím gestikulácie na výučbu znelých a neznelých spoluhlások, použitím pier, zubov a jazyka, zdôrazňovaním určitých slabík alebo použitím vizuálov. Reid (2014) popisuje cvičenia na počúvanie, opakovanie, drilovanie, nahrávanie výslovnosti študentov, jazykolamy a iné ako vhodné na osvojovanie si správnej výslovnosti.

Pre rozvoj ortografickej kompetencie autori odporúčajú v prvom rade zahrnút' množstvo aktivít na čítanie. Študenti si tak môžu všimnút' správny výzor jazyka a zlepšit' si pravopis (Harmer, 2012). Olshtain (2013) odporúča precvičovat' pravopis tým, že dáva žiakom jednoduché úlohy spojené $\mathrm{s}$ písmenami. Dalšou technikou je kopírovanie textov (Harmer, 2015). Rada Európy (2001) navrhuje niekol'ko techník na rozvoj pravopisných schopností. Patria medzi ne zapamätávanie prvkov abecedy, precvičovanie písania, precvičovanie diktátom, alebo zapamätávanie si slovných foriem.

Pri sociolingvistickej kompetencii Reid (2014) navrhuje súbor odporúčaných metód a techník výučby kultúry, ktoré sú založené na CEFR. Patria sem napríklad hry, hranie rolí, simulácie, diskusie, vysvetlenia, ilustrácie, alebo vytváranie portfólií. Podla Byrama (2002) je jedným z najúčinnejších spôsobov vyučovania kultúry používanie autentických materiálov.

Pri rozvíjaní funkčnej kompetencie by učitelia mali klást' dôraz na dostatočné množstvo aktivít približujúcich sa komunikácii v reálnom svete. CelceMurcia (2008) navrhuje simuláciu telefónnych hovorov a písania e-mailov v ciel’ovom jazyku, vytváranie rozhovorov, sumarizácie podstaty textu $\mathrm{s}$ partnerom, hranie rolí, alebo písanie (reklamy, informačné letáky atd'.). Vol'né hovorené aktivity, ako sú situačné hry, dramatizácie alebo diskusie (Kováčiková a Gajdáčová -Veselá, 2016), môžu tiež spĺn̆at potrebu precvičovania funkčného jazyka za predpokladu, že sú dobre naplánované.

$\mathrm{V}$ neposlednom rade, pri diskurznej kompetencii autori odporúčajú prieskumy a rôzne hry rozvíjajúce schopnost' študentov komunikovat' $\mathrm{s}$ druhými. Hranie rolí, simulácie, dráma a techniky rozprávania príbehov pomáhajú simulovat' jazyk skutočného sveta pomocou dlhších úsekov viet. Okrem toho pomáhajú pri získavaní schopnosti slobodne vytvárat' jazyk a striedat' sa v rozhovore. Diskusie môžu byt' spontánne alebo riadené. Okrem toho aktivity ako sú hádanky, hry, čítanie máp, zdielanie názorov, alebo aktivity na prenos informácií pomáhajú žiakom pri zlepšovaní konverzačných 
schopností, pretože sú nútení používat' svoje vlastné jazykové zdroje na plnenie úloh (Richards, 2006). Rôzne písomné úlohy, portfóliá alebo denníky sú považované za vynikajúce techniky na rozvíjanie písania súvislých textov (Thornbury, 2005).

\section{Metodológia výskumu}

Pre náš výskum sme zvolili kvalitatívny prístup s číselnými údajmi. Ked’že naším prvotným ciel'om bolo identifikovanie a preskúmanie daného javu, kvalitatívny prístup nám umožnil získat množstvo dát siahajúcich do híbky problematiky. V štúdii boli položené nasledovné výskumné otázky:

1. Ako vybrané anglické učebnice odkazujú na rozvoj komunikačnej kompetencie z hl'adiska reprezentácie jednotlivých kompetencií?

2. Ako sú jednotlivé zložky komunikačnej kompetencie zastúpené na skutočných hodinách anglického jazyka?

3. Aké stanovisko majú učitelia k rozvoju komunikačnej kompetencie?

\section{Metódy zberu a spracovania dát}

Zvolili sme tri metódy zberu dát - obsahovú analýzu, pozorovanie a rozhovor. Získané informácie boli spracované kódovaním a kategorizovaním.

Pri obsahovej analýze boli analyzované tri vybrané učebnice angličtiny vo 4 . ročníku základných škôl s ohl’adom na komunikačnú kompetenciu. Proces analýzy sa uskutočnil na základe siedmich zložiek komunikačnej kompetencie a ich šestnástich prvkov, ktoré boli popísané $\mathrm{v}$ teoretickej časti štúdie.

Pozorovanie následne prebiehalo v prirodzenom prostredí školských lavíc. Odpozorovalo sa sto hodín angličtiny pomocou polo-štruktúrovaného neúčastníckeho pozorovania. Pre ciele výskumu bola zvolená jedna $\mathrm{z}$ troch analyzovaných učebníc a štyria učitelia, z ktorých každý bol pozorovaný počas dvadsiatich piatich hodín. Tretou metódou bol polo-štruktúrovaný rozhovor s otvorenými otázkami, ktorý sa uskutočnil s 15 učitel'mi. Trval približne 60 minút, a naším hlavným zámerom bolo porozumiet' rozvoju komunikačnej kompetencie z osobného pohl'adu konkrétnych učitel'ov.

\section{Výskumná vzorka}

Výskumnú vzorku sme si volili pre potreby plnenia kvalitatívneho výskumu na dvoch úrovniach - prvou boli tri učebnice anglického jazyka vybrané zámerným výberom a druhou učitelia pre pozorovania a rozhovory volení dostupným výberom. Je dôležité uviest', že pri učitel'och nám úlohu stažoval fakt, že mnohí sa obávali pozorovaní, alebo nechceli pristúpit’ na nahrávanie rozhovorov z rôznych dôvodov.

Učebnice, ktoré sme si zvolili, boli nasledovné: Family and Friends 2, medzinárodná učebnica tvorená pre potreby mnohorakých študentov; Our Discovery Island 3, taktiež medzinárodná učebnica tvorená pre potreby mnohorakých študentov; a slovenská Cool English School 4, ktorá bola vytvorená pre konkrétne potreby slovenských žiakov.

Učitelia boli sme si volili z Nitrianskeho kraja. Dohromady sme vo výskume mali 19 učitel'ov, z čoho 4 boli pozorovaní as 15 sme robili rozhovory. 
Spomedzi učitel'ov bolo 17 žien a 2 muži. Učitelia boli vo veku od 28 do 56 rokov.

\section{Interpretácia výskumných dát}

Zozbierané informácie nám poskytli detailný náhl'ad do procesu rozvíjania komunikačnej kompetencie. Obsahová analýza učebníc popísala všetky kompetencie $\mathrm{v}$ rámci komunikačnej kompetencie. Pozorovania nám potom poskytli náhl'ad do reálnych hodín anglického jazyka. Zistilo sa, ako sa im učitelia venujú, a ktoré z jednotlivých zložiek komunikačnej kompetencie vo vyučovacom procese prevládajú. Rozhovory nám následne umožnili porozumiet' rozvoju skúmaného fenoménu z pohl'adu učitel'ov. Poukázali na to, čo oni sami považujú za dôležité, aké materiály preferujú a akým spôsobom rozvíjajú komunikačnú kompetenciu svojich žiakov.

\section{Obsahová analýza}

Pre tri skúmané učebnice sme zistili, že rozvoj komunikačných kompetencií závisí od jednotlivých učebníc - t.j. každá poníma jednotlivé kompetencie trochu inak. Je t’ažké tieto údaje zovšeobecnit', ale zistili sme, že najkomplexnejšie rozvíjané kompetencie sú lexikálna, gramatická a diskurzná kompetencia.

\begin{tabular}{|c|c|c|c|c|}
\hline \multirow[b]{2}{*}{ Kompetencia } & \multirow[b]{2}{*}{ Zložka } & \multicolumn{3}{|c|}{ Pokrytie } \\
\hline & & $\begin{array}{c}\text { Family } \\
\text { and } \\
\text { Friends } 2\end{array}$ & $\begin{array}{c}\text { Our } \\
\text { Discovery } \\
\text { Island } \mathbf{3}\end{array}$ & $\begin{array}{c}\text { Cool } \\
\text { English } \\
\text { School } 4\end{array}$ \\
\hline Lexikálna & Slová a slovné spojenia & & & \\
\hline \multirow{3}{*}{ Gramatická } & Tvorba viet & & & \\
\hline & Frázy & & & \\
\hline & Slowné druhy & & & \\
\hline $\begin{array}{c}\text { Fonologická a } \\
\text { ortoepická }\end{array}$ & Výslovnost' & & & \\
\hline Ortografická & Hláskovanie a interpunkcia & & & \\
\hline \multirow{2}{*}{ Sociolingvistická } & Pozdravy, predstavovanie sa, oslovovanie, zvolania & & & \\
\hline & Použivanie fráz s prosim, dakujem, ospravedlňujem sa & & & \\
\hline \multirow{6}{*}{ Funkčná } & Oznamovanie a pýtanie sa & & & \\
\hline & Vyjadrovanie postojov & & & \\
\hline & Dohovor & & & \\
\hline & \begin{tabular}{|l|} 
Socializovanie sa \\
\end{tabular} & & & \\
\hline & \begin{tabular}{|l} 
Štruktúra diskurzu \\
\end{tabular} & & & \\
\hline & Oprava komunikácie & & & \\
\hline \multirow{2}{*}{ Diskurzná } & Tvorba rozsahu viet $\mathrm{v}$ hovoreni a pisani & & & \\
\hline & Striedanie sa v komunikácii & & & \\
\hline
\end{tabular}

Obrázok 3. Výsledky obsahovej analýzy učebníc

Vyššie spomínané kompetencie (lexikálna, gramatická a diskurzná) majú vo všetkých troch učebniciach vel'ké zastúpenie s obrovským množstvom rôznych aktivít na precvičovanie. Najzanedbávanejšou kompetenciou je sociolingvistická kompetencia, ktorá je dostatočne zastúpená iba v Cool English School 4. Funkčné kompetencie sú obsiahnuté v dvoch 
medzinárodných učebniciach iba čiastočne, ale Cool English School 4 ich obsahuje s množstvom praktických cvičení. Na druhej strane ortografická kompetencia je najlepšie pokrytá učebnicou Family and Friends 2, zatial' čo ostatné dve učebnice ju pokrývajú iba čiastočne. Fonologická a ortoepická kompetencie je dobre obsiahnutá v Cool English School 4, avšak iba čiastočne vo Family and Friends 2 a Our Discovery Island 3. Na základe týchto informácií možno skonštatovat', že učebnicou, ktorá najkomplexnejšie pokrýva komunikačné kompetencie, je Cool English School 4. Family and Friends 2 a Our Discovery Island 3 ponúkajú excelentné množstvo aktivít pre rozvoj určitých kompetencií, avšak niektoré sú nimi pokryté iba čiastočne alebo nedostatočne.

\section{Pozorovanie}

Pri pozorovaniach sme zistili, že kompetenciami, ktoré prevládali vo vyučovacom procese, sú lexikálna, ortografická a gramatická kompetencia.

\begin{tabular}{|c|c|c|c|c|c|}
\hline \multirow{3}{*}{ Kompetencia } & \multirow{3}{*}{ Zložka } & \multicolumn{4}{|c|}{ Prítomnost' na hodinách } \\
\hline & & \multirow[b]{2}{*}{ Celková } & \multirow[b]{2}{*}{$\begin{array}{l}\text { Prirodzený } \\
\text { rýskyt }\end{array}$} & \multicolumn{2}{|c|}{ Zámerné ryučovanie } \\
\hline & & & & $\begin{array}{l}\text { Počet } \\
\text { ryuč. } \\
\text { hodin }\end{array}$ & $\begin{array}{l}\begin{array}{l}\text { Priemerný } \\
\text { ćas (min.) }\end{array} \\
\text {. }\end{array}$ \\
\hline Lexikálna & Slováa a slovné spojenia & 95 & - & 95 & $5-20$ \\
\hline \multirow{3}{*}{ Gramatická } & \begin{tabular}{|l|} 
Tvorba viet \\
\end{tabular} & 69 & - & 69 & $2-20+$ \\
\hline & Frázy & 71 & - & 71 & $5-20$ \\
\hline & Slovné druhy & 62 & - & 62 & $5-20$ \\
\hline $\begin{array}{c}\text { Fonologická a } \\
\text { ortoepická }\end{array}$ & Výslovnost' & 58 & 22 & 36 & $10-15$ \\
\hline Ortografická & Hláskovanie a interpunkcia & 72 & - & 72 & 10 \\
\hline \multirow[b]{2}{*}{ Sociolingristická } & \begin{tabular}{|l|} 
Pozdravy, predstavovanie \\
sa, oslovovanie, zvolania
\end{tabular} & 100 & 76 & 24 & 10 \\
\hline & $\begin{array}{l}\text { Použivanie fráz s prosim, } \\
\text { dakujem, ospravedlñujem } \\
\text { sa }\end{array}$ & 63 & 58 & 5 & 10 \\
\hline \multirow{6}{*}{ Funkčná } & Oznamovanie a pýtanie sa & 67 & 34 & 33 & 5 \\
\hline & Vyjadrovanie postojov & 49 & 32 & 17 & 10 \\
\hline & Dohovor & 12 & 8 & 4 & 10 \\
\hline & \begin{tabular}{|l|} 
Socializovanie sa \\
\end{tabular} & 100 & 100 & - & - \\
\hline & \begin{tabular}{|l|l|} 
Štruktúra diskurzu \\
\end{tabular} & 0 & - & - & - \\
\hline & \begin{tabular}{|l|} 
Oprava komunikácie \\
\end{tabular} & 0 & - & - & - \\
\hline \multirow{2}{*}{ Diskurzná } & $\begin{array}{l}\text { Tvorba rozsahu viet } \mathrm{v} \\
\text { hovoreni a pisani }\end{array}$ & 20 & - & 20 & $5-15$ \\
\hline & $\begin{array}{l}\text { Striedanie sa v } \\
\text { komunikácii }\end{array}$ & 0 & - & - & - \\
\hline $\begin{array}{l}\text { pokrytie } \\
\text { kompetencii } \\
\text { na hodinách }\end{array}$ & - vynikajúce, & & - čiastočné, & & - žiadne \\
\hline
\end{tabular}

Obrázok 4.

Vyššie spomenuté kompetencie sa objavili vo viac ako $70 \%$ pozorovaných hodín a poskytovali vyvážený rozvoj jazykových znalostí pomocou použitia rôznych materiálov a aktivít. Čas, ktorý im učitelia vo svojom vyučovacom procese venovali bol rôznorodý, avšak vyvážený s dostatočným priestorom pre praktické aj produktívne precvičovanie jazyka. Fonologická a ortoepická kompetencia sa rozvíjala na $36 \%$ hodín, pričom niekol'ko (hlavne suprasegmentálnych) aspektov chýbalo. Pokial' ide o sociolingvistickú, 
funkčnú a diskurznú kompetenciu, rozdelenie medzi jednotlivými zložkami bolo nerovnomerné (od 0 do 33 hodín), avšak žiadna $\mathrm{z}$ týchto troch nepresiahla $33 \%$ z odpozorovaných hodín. Materiály a aktivity, ktoré učitelia použili, boli nepestré a obmedzené v počte. Tieto fakty znázorňujú, že učitelia venujú nadmernú pozornost' výučbe gramatiky, slovnej zásoby a pravopisu, ale zanedbávajú vývoj jazykovej produkcie na funkčné a diskurzné účely, ako aj na jazyk $\mathrm{v}$ rôznych sociálnych a kultúrnych kontextoch.

\section{Rozhovor}

Z rozhovorov sme zistili, že učitelia pod pojmom komunikačná kompetencia rozumejú sociolingvistický a gramatický aspekt jazyka sprevádzaný zručnost'ou hovorenie. Na základe ich d’alších odpovedí sme zistili, že väčšina $\mathrm{z}$ nich považuje lingvistickú kompetenciu (slovnú zásobu, gramatiku a výslovnost') za najdôležitejšiu vo vyučovaní. Iba vel'mi málo z nich považuje pragmatickú kompetenciu (úspešná komunikácia v konkrétnom kontexte) za rovnako dôležitú. Toto sa odzrkadlilo aj v ich odpovediach pri konkrétnych komponentoch komunikačnej kompetencie.

Zistili sme, že učitelia zahŕňajú komponenty lingvistickej kompetencie dostatočne často $\mathrm{s}$ rozmanitým množstvom materiálov a aktivít. Jedinou zložkou lingvistickej kompetencie, ktorú učitelia rozvíjajú len čiastočne, je fonologická a ortoepická (väčšina učitel'ov nepovažuje za dôležité suprasegmentálne aspekty, akými sú vetný prízvuk alebo intonácia). Čo sa sociolingvistickej kompetencie týka, aj napriek tomu, že väčšina učitel’ov považuje túto kompetenciu za dôležitú, iba približne polovica z nich jej aj venuje dostatočnú pozornost' na hodinách. Pri pragmatickej kompetencii učitelia považujú za dôležitú diskurznú kompetenciu, ale len polovica z nich poukazuje rovnako aj na funkčnú. Celkovo tak $\mathrm{z}$ ich odpovedí usudzujeme, že tieto dve kompetencie sú rozvíjané dostatočne len polovicou opýtaných učitelov. Druhá polovica im nevenuje dostatočnú pozornost' na hodinách.

Na záver možno uviest', že učitelia sú si vedomí toho, že kladú vel'ký dôraz na rozvoj lingvistickej kompetencie. Okrem toho zistenia ukazujú, že by chceli zahrnút' viac vyučovania, ktoré by rozvíjalo sociolingvistické a pragmatické kompetencie. Príjemné hodiny a dostatok času na zahrnutie d’alších aktivít pravdepodobne poskytujú vhodné prostredie, ktoré môže pomôct' pri vyváženom rozvoji všetkých zložiek komunikačnej kompetencie. Na druhej strane, učitelia podla ich vlastných slov musia často čelit' výzvam, ktoré môžu mat' negatívny dopad na vyučovací proces (najmä z hl'adiska nedostatku času na prípravu na hodiny, materiály, financie a morálnu podporu inovatívneho vyučovania). Poskytnutie metodickej príručky so špecifickými, dobre prispôsobenými a pripravenými aktivitami na vyvážený rozvoj komunikačnej kompetencie by podla nich mohlo pomôct' pri zvyšovaní efektívnosti vyučovacieho procesu a celkovej komunikačnej kompetencie žiakov.

\section{Diskusia}

Informácie získané z troch výskumných metód nám poskytli komplexné pochopenie komunikačnej kompetencie a jej integrácie do vyučovacieho 
procesu. Na základe zistení týkajúcich sa rozvoja lingvistickej kompetencie možno dospiet' $\mathrm{k}$ záveru, že ide $\mathrm{o}$ najsilnejšiu a najkomplexnejšie rozvíjanejšiu zložku komunikačnej kompetencie. Lexikálna kompetencia bola jednou $\mathrm{z}$ najdominantnejších komponentov vo všetkých troch výskumných metódach. $\mathrm{V}$ prvom rade, zistenia zo všetkých troch učebníc poukázali na vel'kú dôležitost' slovnej zásoby a dostatku príležitostí na jej osvojovanie a precvičovanie. Pozorovania hodín zodpovedali zisteniam z obsahových analýz. Skutočnost', že takmer všetky hodiny obsahovali lexikálny aspekt, potvrdila, že táto kompetencia je $\mathrm{v}$ procese učenia sa zásadná a aj adekvátne rozvíjaná. Rozhovory d’alej odhalili, že lexikálne vedomosti sa považujú za dôležité pri výučbe, a taktiež sa považujú za jednu z najsilnejších stránok samotného vyučovacieho procesu.

Gramatická kompetencia taktiež dominovala vo vyučovacom procese. Analýza učebníc odhalila význam gramatiky a všetkých jej aspektov vo všetkých troch skúmaných učebniciach. $Z$ pozorovaní potom vyplynulo, že viac ako $70 \%$ pozorovaných hodín zahíňalo aspoň jednu $\mathrm{z}$ troch reprezentatívnych zložiek gramatickej kompetencie. Navyše väššina opýtaných učitel'ov potom uviedla, že považuje za nevyhnutné klást' vel'ký dôraz na výučbu gramatiky, pretože že je to jeden z najdôležitejších aspektov jazyka.

Zistenia týkajúce sa fonologickej a ortoepickej kompetencie boli dost' alarmujúce. Po prvé, zistilo sa, že učebnice vnímajú ich vývoj odlišne. Dve medzinárodné učebnice (Family and Friends 2 a Our Discovery Island 3) podporovali rozvoj výslovnosti iba čiastočne, zatial' čo Cool English School 4 obsahovala všetky zložky definované $\mathrm{v}$ referenčných dokumentoch. Z pozorovaní potom vyplynulo, že učitelia sa zaoberali týmito kompetenciami iba na $36 \%$ pozorovaných hodín a podobne ako $\mathrm{v}$ medzinárodných učebniciach, na hodinách zahŕňali iba segmentálnu úroveň rozvoja jazyka (výslovnost' konkrétnych slov a zvuky v slovách). Z rozhovorov vyplynulo, že učitelia považujú výslovnost' za jeden z najdôležitejších aspektov jazyka, ale iba jedna tretina $z$ nich považuje aj jej suprasegmentálne prvky za rovnako dôležité. Navyše uviedli, že tieto kompetencie vel'mi často začleňujú do výučby, čo je $\mathrm{v}$ rozpore so zisteniami z pozorovaní. Na základe týchto informácií sa predpokladá, že fonologické a ortoepické kompetencie sa rozvíjajú iba čiastočne, pretože nie všetky učebnice poskytujú dostatočné pokrytie kompetencií a väčšina učitel’ov sa $\mathrm{v}$ rámci výslovnosti výučby nezaoberá inými prvkami, ako sú segmentálne.

Ortografická kompetencia bola vel'mi podobná lexikálnej a gramatickej kompetencii - prevládala vo vyučovacom procese. Zistilo sa, že z troch učebníc Family and Friends 2 zahrňuje túto kompetenciu najlepšie. Tieto zistenia korešpondovali s pozorovaniami aj rozhovormi, ktoré ukázali, že pre všetkých učitel'ov je nevyhnutné správne písanie a že ho tiež vel'mi často začleňujú do hodín. $Z$ pozorovaní vyplynulo, že viac ako $70 \%$ hodín zahíňalo rozvoj pravopisu do vyučovacieho procesu.

Na základe údajov týkajúcich sa sociolingvistickej kompetencie sa zistilo, že ani jedna medzinárodná učebnica sa nezaoberá praktickými ani produktívnymi aktivitami na jej rozvoj dostatočne. Jediná, ktorá poskytuje dostatočné pokrytie pre vyvážený rozvoj tejto kompetencie, je Cool English 
School 4. Z pozorovaní vyplynulo, že učitelia síce požadujú od svojich žiakov, aby používali jazyk v rôznych situáciách ako súčast' tzv. „classroom language“ (jazyk použivaný na hodine na iné než vyučovacie účely), ale iba málo hodín sa v skutočnosti venuje zámernému vyučovaniu kompetencie, a aj to len pasívnym precvičovaním bez možnosti praktického precvičovania. Rozhovory potom poukázali na to, že všetci učitelia považujú sociolingvistickú kompetenciu za dôležitú, ale iba polovica z nich venuje dostatok úsilia na jej rozvoj pomocou rôznych materiálov a aktivít. Na základe týchto informácií dochádzame k záveru, že skutočný vyučovací proces neposkytuje žiakom dostatok príležitostí na správne rozvíjanie sociolingvistickej kompetencie. Predpokladá sa, že ak by učitel’om bola poskytnutá učebnica pokrývajúca všetky zložky kompetencie dostatočne (napríklad ako Cool English School 4), alebo metodické usmernenie o tom, ako implementovat' rôzne aktivity na pomoc pri rozvíjaní tejto kompetencie, výsledky by boli ovel'a priaznivejšie.

Zistenia pragmatickej kompetencie sa odlišovali pri všetkých troch metódach. Pokial' ide o funkčnú kompetenciu, $\mathrm{z}$ analýzy učebníc vyplynulo, že Cool English School 4 poskytuje najlepšie pokrytie jej komponentov. Dve medzinárodné učebnice poskytujú iba čiastočný rozvoj kompetencie, pričom $\mathrm{z}$ nich úplne chýba až niekol'ko komponentov. Zistenia $\mathrm{z}$ pozorovaní zodpovedali informáciám z analýzy učebníc. Napriek častému prirodzenému výskytu niektorých zložiek funkčnej kompetencie na hodinách zámerné vyučovanie bolo venované iba krátkemu, pasívnemu precvičovaniu jazykových štruktúr $\mathrm{v}$ menej ako $33 \%$ pozorovaných hodín. $\mathrm{Z}$ rozhovorov následne vyplynulo, že iba polovica učitel'ov považuje funkčnú kompetenciu za dôležitú, zatial' čo ostatní tvrdili, že na základnom stupni nie je nevyhnutná.

Na druhej strane, diskurzná kompetencia je vel’mi dobre zahrnutá vo všetkých troch analyzovaných učebniciach. Bohaté pokrytie všetkých zložiek kompetencie a vel'ké množstvo aktivít zabezpečuje vyvážený rozvoj tejto kompetencie po celej dížke všetkých učebníc. Zistenia z pozorovaní tomu však nezodpovedajú. $Z$ celkového počtu 100 hodín sa iba 20 venovalo rozvoju diskurznej kompetencie. Rozhovory potom odhalili, že hoci väčšina učitel'ov považuje túto kompetenciu za dôležitú, iba približne polovica z nich sa zaoberá jej vyváženým vývojom $\mathrm{v}$ skutočnom vyučovacom procese. $\mathrm{Na}$ základe týchto informácií je zrejmé, že aj ked' učebnice poskytujú dostatok príležitostí na precvičenie jednotlivých častí komunikačných kompetencií, nezaručuje to, že ich budú obsahovat’ aj reálne hodiny.

\section{Záver}

Jednotlivé výskumné metódy nám poskytli pohlad na to, ako sa vo vyučovacom procese zaobchádza s komunikačnými kompetenciami. Analýzy učebníc odhalili, že iba jedna $\mathrm{z}$ troch analyzovaných učebníc je $\mathrm{v}$ takmer úplnom súlade s požiadavkami referenčných dokumentov. $\mathrm{V}$ d’alších dvoch učebniciach sú menšie alebo väčšie nedostatky viacerých zložiek komunikačnej kompetencie. $\mathrm{Na}$ základe tejto skutočnosti môžeme konštatovat', že nie všetky učebnice poskytujú komplexné pokrytie všetkých komponentov komunikačnej kompetencie. Práve preto by bolo potrebné nájst' 
riešenie $\mathrm{v}$ oblasti kompenzácie chýbajúcich prvkov komunikačnej kompetencie doplňujúcimi metodologickými usmerneniami, materiálmi, alebo konkrétnymi aktivitami na hodinách. Pozorovania a rozhovory $\mathrm{s}$ učitel'mi, ktorí učia z učebnice nedostatočne pokrývajúcej komunikačnú kompetenciu, však odhalili, že nielen na chýbajúce prvky sa často zabúda; ale aj na tie komponenty, ktoré sú $\mathrm{v}$ učebnici zastúpené vynikajúco. Kompetencie, ktoré sú z vyučovacieho procesu vynechávané najčastejšie, sú sociolingvistické a pragmatické kompetencie. $Z$ toho môžeme vyvodit' záver, že aj ked' učitelia tvrdia, že precvičovanie používania jazyka v rôznych komunikačných situáciách a v skutočnom živote je dôležité, nevedia, ako ich efektívne implementovat' do vyučovacích hodín. Skutočnost', že výsledky potvrdili lingvistickú kompetenciu ako jedinú z troch zložiek komunikačnej kompetencie ako dominujúcu vo vyučovacom procese, je vel'mi silným náznakom toho, že komunikačné vyučovanie s dostatočným množstvom praktických cvičení na prípravu študentov používat jazyk v reálnom svete mimo školských lavíc je ešte stále značne zanedbávané.

\section{Bibliographic references}

BACHMAN, L. F. 1990. Fundamental considerations in language testing. Oxford: Oxford University Press, 408 p. ISBN 9780194370035

BACHMAN, L.F. - PALMER, A. S. 1996. Language testing in practice: Designing and Developing Useful Language Tests. OUP, Oxford, $377 \mathrm{p}$. ISBN 9780194371483

BYRAM, M. - GRIBKOVA, B. - STARKEY, H. 2002. Developing the Intercultural Dimension in Language Teaching: A Practical Introduction for Teachers. Strasbourg: Council of Europe, 41 p. Available online: https://rm.coe.int/16802fc1c3

CANALE, M - SWAIN, M. 1980. Theoretical Bases of Communicative Approaches to Second Language Teaching and Testing, In: Applied Linguistics, vol. I, n. 1, pp. 1-47, Available online: https://doi.org/10.1093/applin/I.1.1

CANALE, M. 1983. From communicative competence to communicative language pedagogy. In: Richards J, Schmidt, R.. Language and Communication. 1983. Longman, London, pp 2-27.

CELCE-MURCIA, M. - DORNYEI, Z. - THURRELL, S. 1995. A pedagogical framework for communicative competence: A Pedagogically motivated model with content specifications. In: Issues in Applied Linguistics, vol. 6, n. 2, pp. 5-35

CELCE-MURCIA, M. 1991. Teaching English as a Second or Foreign Language. $2^{\text {nd }}$ ed. Heinle\&Heinle Publishers, 567 p. ISBN 9780838428603

CELCE-MURCIA, M. 2008. Rethinking the Role of Communicative Competence in Language Teaching. In: Soler, E. A.- Jorda Safont, M.P. (eds.), Intercultural Language Use and Language Learning. Springer, Dordrecht, pp 41-57. ISBN 978-1-4020-5639-0.

COUNCIL OF EUROPE. 2001. The Common European Framework of Reference for Languages: Learning, Teaching and Assessment. Cambridge, U.K: Press Syndicate of the University of Cambridge. 273 p. ISBN 978-92871-8233-3 
GOWER, R. 1995. Teaching Practice Handbook. Oxford : Heinemann, 215 p. ISBN 0-435-24059-5

HARMER, J. 2012. Essential Teacher Knowledge : Core Concepts in English Language Teaching. Harlow, England : Pearson Education Ltd. 288 p. ISBN 9781408268049

HARMER, J. 2015. The Practice of English Language Teaching. Harlow: Pearson, 2015. 5th ed. 446 p. ISBN 9781447980254

HOMOLOVA, E. 2016. Teaching English. Banská Bystrica: Belianum, 110 p. ISBN 9788055711027

HYMES, D. 1972. On communicative competence. In: J. B. Pride and J. Holmes (eds.): Sociolinguistics. Harmondsworth: Penguin. pp. 269-293.

CHOMSKY, N. 1965. Aspects of the theory of syntax. Cambridge, MA: MIT Press, 270 p.

KOVACIKOVA, E.- VESELA, K. G. 2016. Zaklady didaktiky cudzích jazykov. Nitra: UKF. 147 p. ISBN 978-80-558-1050-8.

LARSEN-FREEMAN, D - ANDERSON, M. 2013. Techniques and Principles in Language Teaching 3rd edition - Oxford Handbooks for Language Teachers. $3^{\text {rd }}$ ed. Oxford University Press, 272 p. ISBN 9780194342674

LITTLEWOOD, W. 2011. Communicative language teaching: An expanding concept for a changing world. In E. Hinkel (ed.), Handbook of Research in Second Language Teaching and Learning, Volume II . New York: Routledge. pp. 541-547.

NETTO-SHEK, J. A. 2009. Teaching Grammar. In Wong, R. E. L., Developing Literacy in the English Classroom: Engaging Primary Pupils, Pearson Education, pp 116-135. ISBN 978-9810682743

OLSHTAIN, E. 2013. Practical Tasks for Mastering the Mechanics of Writing and Going Just Beyond. In: Celce-Murcia, M. et. al (Ed) Teaching English as a Second or Foreign Language. US: Heinle Cengage Learning, pp. 208-221. ISBN 978-1111351694

PETERS, D. - FEUNTEUN, A. 2012. Our Discovery Island 3: Pupil‘s Book. Pearson, 88 p. ISBN 9781408238745

PETERS, D. 2012. Our Discovery Island 3 activity book. Pearson, 72 p. ISBN 9781408251287

REID, E. 2014. Intercultural Aspects in Teaching English at Primary Schools. Peter Lang GmbH. 135 p. ISBN 978-3631655535

REID, E. et al. 2017. Cool English School 4: pupil's book. Kosice : TAKTIK, 103 p. ISBN 978-80-8180-043-6.

REID, E. et. al. 2017. Cool English School 4 : workbook. Kosice : TAKTIK, 87 p. ISBN 978-80-8180-042-9.

RICHARDS, J. 2006. Communicative Language Teaching Today. Cambridge University Press, 52 p. ISBN 978052195129. Available online: https://www.professorjackrichards.com/wp-content/uploads/Richards-

Communicative-Language.pdf

RICHARDS, J. C. - RODGERS, T. S. 2014. Approaches and Methods in Language Teaching. $1^{\text {st }}$ ed. Cambridge University Press, 410 p. ISBN 9781107675964 
RINVOLUCRI, M. - DAVIS, P. 1995. More Grammar Games. Cambridge University Press, 176 p. ISBN 9780521466301

SAVIGNON, S. J. 1972. Communicative Competence: An Experiment in Foreign-Language Teaching. Language and the Teacher. In: Applied Linguistics, vol. $12.115 \mathrm{p}$.

SCRIVENER, J. 2011. Learning Teaching. MacMillan, 416 p. ISBN 9780230729841

SIMMONS, N. 2009. Family and Friends 2 : class book . Oxford : Oxford University Press, 111 p. ISBN 978-0-19-481218-4.

SIMMONS, N. 2009. Family and Friends 2 : workbook. Oxford : Oxford University Press, 119 p. ISBN 978-0-19-481213-9.

THORNBURY, S. 2005. How to Teach Speaking. $1^{\text {st }}$ ed. Pearson Education Limited, 2005. 160 p. 978-0582853591

TRIM, J. L.M. 2001. Breakthrough. Unpublished manuscript. Available online: http://www.englishprofile.org/928-uncategorised/120-breakthrough

VALENTZAS, J. - BRONI, G. 2014. Communication Cycle: Definition, Process, Models and Examples. In: RECENT ADVANCES in FINANCIAL PLANNING and PRODUCT DEVELOPMENT. WSEAS Press. pp 171-131. ISBN 978-1-61804-261-3,

WIDDOWSON, H.G. 1978. Teaching Language as Communication. OUP Oxford, 168 p. ISBN 9780194370776

Mgr. Klaudia Pauliková, PhD.

Department of Language Pedagogy and Intercultural Studies

Faculty of Education

Constantine the Philosopher University

Drazovska 4

94974 Nitra

Slovakia

kpaulikova@ukf.sk 